\title{
Resistance of Quiescent Human Diploid Fibroblasts to High Dose of External Oxidative Stress and Induction of Senescence
}

\author{
Danijela Domazet-Damjanov, Mallika Somayajulu-Nițu and Siyaram Pandey*
}

Department of Chemistry and Biochemistry, University of Windsor, Windsor, Ontario, Canada

\begin{abstract}
In response to external oxidative stress/DNA damaging agents, mammalian cells may choose one of the following pathways to avoid propagation of the damaged cells: repair the DNA and proceed with the normal cell cycle; trigger apoptosis; or undergo senescence to block cell division. If these safeguard mechanisms fail, cells containing damaged/mutated DNA will continue to propagate leading to cancer. Working with Human Diploid Fibroblasts, we have observed that young quiescent fibroblasts, unlike dividing fibroblasts, do not undergo apoptosis when subjected to high dose of external oxidative stress. Interestingly, when those quiescent fibroblasts are sub-cultured following $\mathrm{H}_{2} \mathrm{O}_{2}$ treatment, they display all the features of the senescent cell phenotype. Our results have indicated that p21 and MnSOD over-expression in quiescent cells is highly correlated to resistance to oxidative stress and may induce senescence. Moreover, there was no observable DNA damage in quiescent fibroblasts after $500 \mu \mathrm{M} \mathrm{H}_{2} \mathrm{O}_{2}$ treatment even though oxidative damage to lipids and proteins was detected both before and after treatment. Most importantly, the mitochondrial membrane potential in quiescent cells remained unchanged even after exposure to a high dose of external oxidative stress. In dividing cells, Bcl-2 expression was down-regulated whereas Bax expression was up-regulated following oxidative stress. On the other hand, Bcl-2 levels remained high and Bax was down-regulated in quiescent cells under identical treatment. Our results reveal that the over-expression of p21 and Mn-SOD and the down-regulation of Bax in quiescent cells could be responsible for their resistance against external oxidative stress and onset of senescence.
\end{abstract}

Keywords: Oxidative stress, stress induced premature senescence, MnSOD, DNA double stranded breaks.

\section{INTRODUCTION}

The free radical theory of aging proposes that the mitochondria of aged animals are compromised leading to increased production of reactive oxygen species (ROS) when compared with younger animals [1]. In culture, Normal Human Fibroblast (NHF) cells are capable of undergoing a set number of population doublings (PD) termed the "Hayflick limit" [2]. At this point they enter a state of permanent growth arrest known as cellular or replicative senescence [3]. Senescent NHFs stop replicating but still remain metabolically active. Senescent and dividing NHFs differ with respect to morphology (senescent cells are larger and have lower cell density), gene expression patterns, senescence-associated (SA)- $\beta$-galactosidase activity and telomere length [4-6]. Senescent cells typically have higher level of ROS, which attack and damage the DNA causing 8oxo-2'-deoxyguanosine ( oxo $^{8} \mathrm{dG}$ ) $[7,8]$. Alternate stresses, such as exposure to ultraviolet light, tertbutylhydroperoxide (tBHP), hyperoxia and external oxidative stress, like $\mathrm{H}_{2} \mathrm{O}_{2}$, can make cells withdraw prematurely from cell cycle [9-12]. This phenomenon of induced senescence is termed stressinduced premature senescence (SIPS) and cells undergoing SIPS possess the standard features of replicative senescence: similar morphology, cell cycle regulation, SA- $\beta$-galactosidase activity, amongst other features [5, 7]. Chronic lowdose $\mathrm{H}_{2} \mathrm{O}_{2}$ treated dividing NHFs, as well as senescent NHFs, are blocked in G1 stage of the cell cycle [8]. An

*Address correspondence to this author at the Chemistry and Biochemistry, University of Windsor, Windsor, ON N9B 3P4, Canada; Tel: (519) 2533000, Ext: 3701; Fax: (519) 973-7098; E-mail: spandey@uwindsor.ca increase in cell cycle inhibitor CDKI p $21^{\text {Waf- } 1}$ levels in presenescent cells and NHFs after the induction of SIPS is observed in these cells, explaining cell cycle arrest [13].

An important consequence of oxidative stress is DNA damage. Depending upon the extent of damage, cells can either commit to cell death or cellular senescence through common p53-dependent mechanism [14]. If DNA damage is not severe enough to induce apoptosis but is also not repairable by DNA repair mechanisms, such as nucleotide/ base excision or mismatch repair, then cellular senescence occurs $[15,16]$. Oxidative stress is the major cause of telomere shortening, and it has been observed that telomeres are lost five to ten times faster when cells are subjected to chronic hyperoxia [17]. Telomere shortening is observed in cell populations undergoing SIPS as well as observed in cells that managed to regain their proliferation ability several days after the stress was induced [18].

Here we report the results of a novel approach in inducing senescence in NHFs by brief exposure to a high dose of $\mathrm{H}_{2} \mathrm{O}_{2}$ in quiescent stage. We have attempted to reveal the mechanism underlying the onset of oxidative stress induced senescence in quiescent NHFs by monitoring protein expression, DNA damage and levels of reactive oxygen species (ROS) at the cellular level. We have previously reported that oxidative stress induces p38MAPK and causes apoptosis in young dividing NHFs [19]. Interestingly, as opposed to the young dividing NHFs that underwent apoptosis, quiescent cells showed resistance to a high dose of oxidative stress. These quiescent cells could not divide after sub-culturing and showed senescent phenotype. Of equal interest is deciphering the mechanism how the contact 
inhibition of cultured cells leads to up-regulation of antioxidant system.

We have observed an up regulation of p21 and Mn-SOD was observed in quiescent cells, which may be a possible explanation for their resistance to apoptosis and onset of senescence.

\section{MATERIALS AND METHODS}

\section{Cell Culture}

Normal Human Fibroblasts (AG09309 and AG09319) were obtained from Coriell Institute for Medical research (New Jersey, USA) and grown in Dulbecco's Modified Eagle's Medium supplemented with 15\% FBS (Sigma, Mississauga) in $5 \% \mathrm{CO}_{2}$ in a humid incubator at $37^{\circ} \mathrm{C}$. All the cells used had a population doubling between 20 and 25 .

\section{Induction of SIPS and Apoptosis in Quiescent and Dividing NHFs, Respectively}

Cells were grown either to $50 \%$ or $100 \%$ confluence. NHF in early population doubling (PD 14) are capable of dividing at optimum growth rate when they are at $50 \%$ confluence, we designate these as dividing NHFs. Cell grown to $100 \%$ confluence and maintained at this confluence for 72 hours, are contact-inhibited (unable to divide) referred as quiescent cells. The growth medium was replaced with fresh Minimum Essential Medium Eagle (Sigma, Mississauga) medium, which was not supplemented with serum. Cells were then treated with $500 \mu \mathrm{M} \mathrm{H}_{2} \mathrm{O}_{2}$ for 1 hour at $37^{\circ} \mathrm{C}$, after which the media was replaced with fresh Dulbecco's Modified Eagle Medium (Sigma, Mississauga) supplemented with $15 \%$ FBS. Cells were allowed to recover for different periods of time, as indicated by the figures and used to perform different experiments.

\section{Senescence-Associated (SA)- $\beta$-galactosidase Stain}

Cells were treated as previously described by [5]. Briefly, cells were washed in PBS, fixed for 3-5 min (room temperature) in $3 \%$ formaldehyde, washed, and incubated at $37^{\circ} \mathrm{C}$ (no $\mathrm{CO}_{2}$ ) with fresh senescence associated $\beta$-Gal (SA- $\beta-\mathrm{Gal}$ ) stain solution: $1 \mathrm{mg}$ of 5-bromo- 4-chloro-3-indolyl $\beta$-Dgalactoside $(\mathrm{X}-\mathrm{Gal})$ per $\mathrm{ml}$ (stock $=20 \mathrm{mg}$ of dimethylformamide per $\mathrm{ml}$ ) $/ 40 \mathrm{mM}$ citric acid/sodium phosphate, $\mathrm{pH}$ $6.0 / 5 \mathrm{mM}$ potassium ferrocyanide $/ 5 \mathrm{mM}$ potassium ferricyanide/150 mM NaCl/ $2 \mathrm{mM} \mathrm{MgCl} 2$. Staining was maximal in $12-16 \mathrm{~h}$.

\section{Cellular Microscopy}

Cells were grown and treated as described above and stained with Hoechst 33342, $10 \mu \mathrm{M}$ final concentration (Molecular Probes, Eugene, OR). Then, they were examined under a fluorescent microscope (Zeiss, Axiovert 200), and both phase contrast and fluorescence pictures were taken and processed using Northern Eclipse 6.0 software. Alternatively, cells were stained with Trypan Blue (Sigma, Mississauga) at various points following the treatment, and counted using hemocytometer. Microsoft Excel version 6.0 software was used for data representation and statistical analysis. Statistica software was used to analyse statistical significance.

\section{Measurement of Total Cell ROS}

Cells were grown and treated as described above. Production of ROS was measured after the cells were treated for 1 hour with $500 \mu \mathrm{M} \mathrm{H}_{2} \mathrm{O}_{2}$, and allowed to recover for 24 hours after hydrogen peroxide treatment by membrane permeable dye 2'-7'- dichlorofluorescin diacetate (DCFDA) obtained from Molecular Probes (Eugene, OR) using a modification of a previously published procedure [20]. Briefly, at various time points after treatment with hydrogen peroxide, cells were incubated with DCFDA to a final concentration of $10 \mu \mathrm{M}$ for $20 \mathrm{~min}$ at $37^{\circ} \mathrm{C}$, and fluorescence (Ex. $495 \mathrm{~nm}$ and Em. 530nm) was measured using a Spectra Max Gemini XS multi-well plate fluorescence reader (Molecular Device, Sunnyvale, California). Cells were counted and the ROS production was expressed as fluorescence units per 10,000 cells. Microsoft Excel version 6.0 software was used for data representation and statistical analysis. Statistica software was used to analyse statistical significance.

\section{Western Blots}

Treated or untreated cultured cells were scraped, washed three times in PBS, and lysed in a lysis buffer consisting of 1 $\mathrm{mM}$ EDTA, $10 \mathrm{mM}$ HEPES, and $250 \mathrm{mM}$ sucrose. The buffer contained protease inhibitors: leupeptin, pepstatin (both at $1 \mu \mathrm{M})$ and PMSF $(0.1 \mathrm{mM})$. The cell suspensions were homogenized in a glass homogenizer and incubated on ice for $20 \mathrm{~min}$. The post-nuclear lysates were isolated by centrifugation, and equal amount of proteins per lane $(20 \mu \mathrm{g})$ were resolved on a $12 \%$ SDS gel. Proteins were electro transferred on to a nitrocellulose membrane. The membranes were blocked with 5\% non-fat milk and probed with antiBax, anti-p21, anti-Bcl-2, anti-actin, anti-Mn-SOD, and antinon-Selenium Glutathione Peroxidase (Sigma, Mississauga). The blots were washed and exposed to HRP-conjugated secondary antibodies (Sigma, Mississauga) and then developed using Chemiluminescence Peroxidase Substrate kit (Sigma, Mississauga, ON) and visualized with Alpha Innotech Corporation Imaging System (San Leonardo, CA). The molecular masses of the proteins were estimated relative to Page Ruler Prestained Protein Ladder (Fermentas Life Sciences, Burlington, ON). Image J software was used for densitometry analysis.

\section{Mitochondrial Membrane Potential}

NHF cells were grown and treated with $\mathrm{H}_{2} \mathrm{O}_{2}$ as previously described. After $24 \mathrm{hrs}$ post $\mathrm{H}_{2} \mathrm{O}_{2}$ treatment, the cells were incubated in culture medium containing $5 \mu \mathrm{g} / \mathrm{ml}$ $\mathrm{JC}-1$ for $20 \mathrm{~min}$ as per the manufacturer's protocol. The JC-1 dye accumulates in the mitochondria of healthy cells as aggregates, which fluoresces red. Upon the collapse of the mitochondrial potential, JC-1 dye can no longer accumulate in the mitochondria and remains in the cytoplasm in a monomeric form which fluoresces green. The distribution of the red and green forms of the dye is simply analyzed by fluorescence microscopy. Upon incubation with JC-1 dye, the cells were observed under a fluorescent microscope (Leica DM IRB), and pictures were processed using Adobe Photoshop 7.0 software. 


\section{Oxidative Stress Markers Staining}

NHFs were grown on cover-slips and treated for 1 hour with $500 \mu \mathrm{M} \mathrm{H}_{2} \mathrm{O}_{2}$ as previously described. 24h after the treatment, the cells were washed with PBS, and fixed in $2 \%$ paraformaldehyde. Following fixation, they were washed in PBS again, and incubated in 70\% ethanol for 5 minutes. At this point they were washed again and incubated in blocking solution containing $10 \%$ FBS in PBS for 1 hour. The cells were then incubated with either anti-NT antibody (Sigma, Mississauga, ON) or anti-4-HNE (Sigma, Mississauga, ON) antibody, diluted 1:500 in antibody diluents for 1 hour. Following primary antibody incubation, the cells were washed with PBS, and incubated with FITC conjugated antirabbit antibody (Sigma, Mississauga), diluted 1:200, for 1 hour. Finally, NHFs were washed in PBS and the cover-slips were mounted onto slides using Ultra CruzTM Mounting Medium with DAPI (Santa Cruz Biotechnology, California). DAPI is a fluorescent stain that binds to DNA strongly. It is used extensively in fluorescence microscopy. Since DAPI can pass through an intact cell membrane, it is used to stain live and fixed cells. The slides were observed and the pictures were taken using fluorescent microscope (Leica DM IRB).

\section{TUNEL Assay}

NHF cells were grown on cover-slips and treated with $\mathrm{H}_{2} \mathrm{O}_{2}$ as previously described. After 24 hours post treatment, the cells were tested for DNA damage using APO-BrdUTM TUNEL Assay kit (Invitrogen Molecular Probes) and manufacturer's recommended protocol. TUNEL (terminal deoxynucleotidyl transferase) is commonly used for detecting DNA fragmentation that results during apoptosis. The nicks in the DNA can be identified by terminal deoxynucleotidyl transferase, an enzyme that catalyzes the addition of dUTPs that are secondarily labeled with a marker. Following the TUNEL labeling, the cover-slips were mounted on slides using Ultra Cruz ${ }^{\mathrm{TM}}$ Mounting Medium with DAPI (Santa Cruz Biotechnology, California). The slides were observed and the pictures were taken using fluorescent microscope (Leica DM IRB).

\section{$\gamma H 2 A X$ Staining for Double Stranded DNA Breaks}

Immunofluorescent microscopy was performed as described by Yang et al. (2002) [21] but with minor modifications. Briefly, cells were seeded into 6-well culture plate containing a glass cover slip in each well to either $50 \%$ or $100 \%$ confluence. After the treatment described above, cells were allowed to recuperate for $1 \mathrm{hr}$ or $24 \mathrm{hrs}$, after which they were fixed in $2 \%$ para formaldehyde for $10 \mathrm{~min}$, washed with PBS, and permeabilized in $70 \%$ ethanol. After blocking with blocking serum for $1 \mathrm{hr}$, slides were incubated with a mouse monoclonal anti- $\gamma \mathrm{H} 2 \mathrm{AX}$ antibody (Sigma, Mississauga), 1:200 dilution for $1 \mathrm{hr}$, followed with FITCconjugated goat-anti-mouse secondary antibody (Sigma, Mississauga), 1:200 dilution for 1 hour. Following the $\gamma \mathrm{H} 2 \mathrm{AX}$ labeling, the cover-slips were mounted on glass slides using Ultra $\mathrm{Cruz}^{\mathrm{TM}}$ Mounting Medium with DAPI (Santa Cruz Biotechnology, California). The slides were observed and the pictures were taken using fluorescent microscope (Leica DM IRB).

\section{RESULTS}

\section{Response of Dividing and Quiescent NHFs to High Dose of External Oxidative Stress}

In order to determine if young dividing and quiescent cells respond differently to a high dose of oxidative stress, we treated them with $500 \mu \mathrm{M} \mathrm{H}_{2} \mathrm{O}_{2}$ for $1 \mathrm{hr}$ as described in Materials and Methods section. Cells were stained and monitored $24 \mathrm{hr}$ following the treatment, for the indication of apoptosis using Hoechst staining and TUNEL labeling. Young dividing fibroblasts $(50-70 \%$ confluence $)$ are vulnerable to high levels of $\mathrm{H}_{2} \mathrm{O}_{2}$ and start undergoing apoptosis (Fig. 1A). Fig. (1B) shows the growth curve for untreated young NHFs. In this study, there was a significant increase in the number of cells undergoing apoptosis on day 1 and 2 after treatment $(\mathrm{p}<0.05$ between day 0 and day1, $\mathrm{p}<0.05$ between day 1 and day 2) as indicated by chromatin condensation observable in Hoechst stain (Fig. 2A) and TUNEL labeling (Fig. 2B). Untreated cells show normal nuclear morphology and no TUNEL labeling (Fig. 2B). Interestingly, quiescent NHFs $(100 \%$ confluence) resisted the stress and did not show nuclear condensation or DNA fragmentation (Fig. 2A,B). Only treated young dividing NHFs were positively labelled by TUNEL assay, as indicated by bright green staining (Fig. 2B). Similarly, Hoechst revealed chromatin condensation in young dividing treated NHFs only (Fig. 2A), as indicated by bright nuclear stain and decreased nucleus size. The quiescent cells remained attached and retained healthy nuclear and cellular morphology. The negative TUNEL labeling indicated that there was no DNA fragmentation. These results indicated that young dividing NHFs underwent apoptosis due to high dose of external oxidative stress, while quiescent NHFs showed resistance. However, TUNEL labeling is too crude a method to detect repairable DNA damage, so the more sensitive $\mathrm{H} 2 \mathrm{AX} \gamma$ staining was carried out. $\mathrm{H} 2 \mathrm{AX} \gamma$ antibody targets phosphorylated $\mathrm{H} 2 \mathrm{AX}$ histone, which is essential for DNA double strand break repair [22]. Our results indicate that $500 \mu \mathrm{M} \mathrm{H} \mathrm{H}_{2} \mathrm{O}_{2}$ exposure creates DNA double strand breaks and initiates an active DNA repair response in quiescent NHFs, visualized as bright foci after $1 \mathrm{hr}$ (Fig. 3A, B). The $\mathrm{H} 2 \mathrm{AX} \gamma$ foci have diminished by $24 \mathrm{hrs}$ posttreatment, which indicates that substantial DNA repair has occurred. On the other hand, young dividing fibroblasts maintain high phosphorylation of $\mathrm{H} 2 \mathrm{AX}$, indicating a high level of DNA double stranded breaks (Fig. 3A,B). In addition, it seems that DNA damage is not successfully repaired after $24 \mathrm{hrs}$ (as seen by TUNEL labeling and Hoechst staining), which leads to apoptosis.

\section{Induction of Senescence by $\mathrm{H}_{2} \mathrm{O}_{2}$ Treatment in Quiescent NHFs}

Although the quiescent NHFs did not show any sign of apoptosis following a high dose of oxidative stress, the question remained if they have undergone any biochemical changes under these circumstances. When these cells were sub-cultured $72 \mathrm{hrs}$ following the $\mathrm{H}_{2} \mathrm{O}_{2}$ treatment, we observed that they lost their ability to divide. Following subculturing, we monitored cell growth for untreated quiescent cells as well as treated cells. The results indicate that total cell number is effectively unchanged over a period of 6 days 

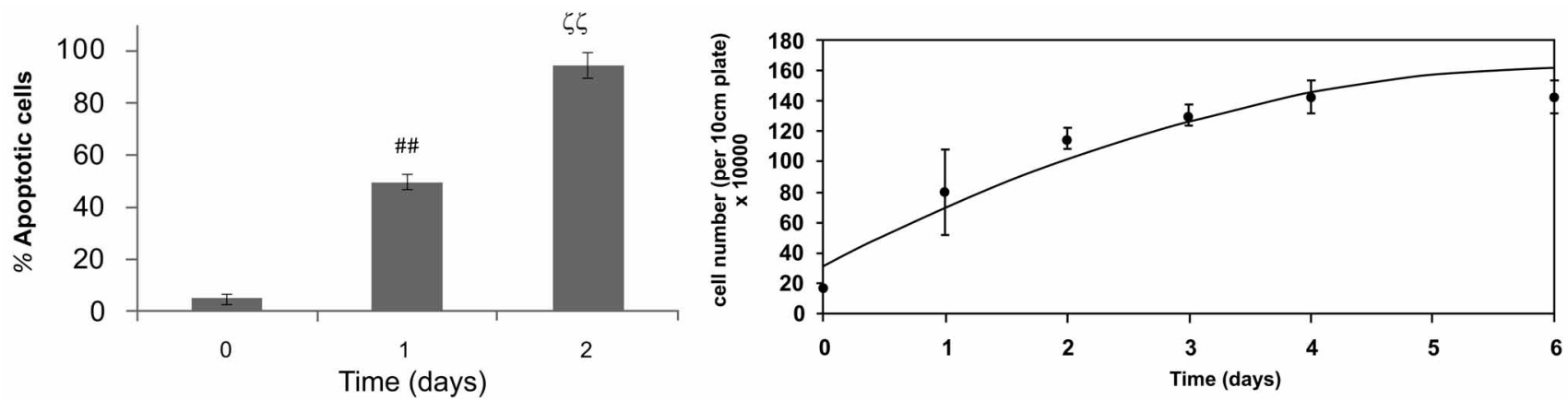

Fig. (1). (A) Dividing NHFs undergoing apoptosis after $\mathbf{H}_{2} \mathbf{O}_{2}$ treatment. Young dividing NHFs (PD26) were treated with 500 $\mu M \mathrm{H}_{2} \mathrm{O}_{2}$ and stained with Hoechst as described in Materials and Methods section. The number of apoptotic cells was monitored over a period of 2 days and represented as percentage of total cell population. Statistically significant differences are shown as: \# between day 0 and day1, $\mathrm{p}<0.05$ and $\zeta$ between day 1 and day 2, p<0.05. (B) Untreated NHF growth curve. Young dividing NHFs (PD 26) were grown to approximately $80-90 \%$ confluence and passaged. The number of cells in the culture was monitored over a period of 2-6 days, starting at the time when they were seeded into new plates. Cells were stained with Trypan blue and counted using a hemocytometer.

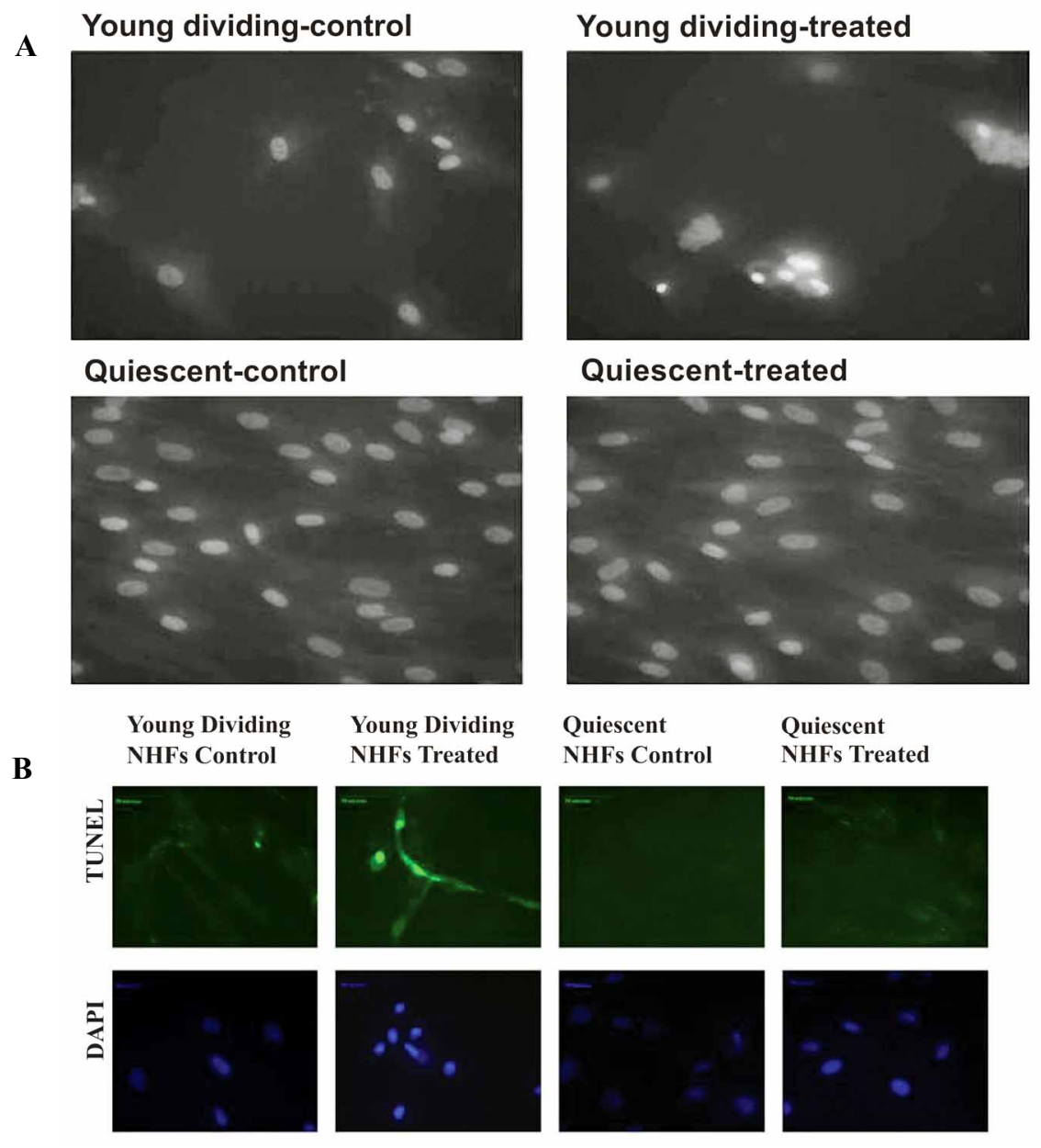

Fig. (2). (A) Nuclear morphology of sub-confluent and quiescent NHFs before and after $\mathrm{H}_{2} \mathrm{O}_{2}$ treatment. Young dividing NHFs and quiescent NHFs were treated with $500 \mu \mathrm{M} \mathrm{H}_{2} \mathrm{O}_{2}$ and stained with Hoechst as described in Materials and Methods section. Pictures were taken at 400x magnification. (B) External oxidative stress induced DNA fragmentation and chromatin condensation in sub-confluent NHFs. Young dividing NHFs and quiescent NHFs were treated with $500 \mu \mathrm{M} \mathrm{H}_{2} \mathrm{O}_{2}$, subjected to TUNEL labeling, and stained with DAPI as described in Materials and Methods section. Pictures were taken at 400x magnification. DNA fragmentation was indicated by positive TUNEL staining, and it was observed only in young dividing NHFs following oxidative stress. DAPI stained brightly only apoptotic collapsing nuclei, confirming the DNA damage in young dividing treated fibroblasts. 


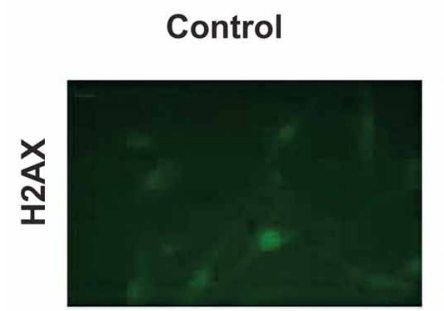

$1 \mathrm{hr}$ post treatment
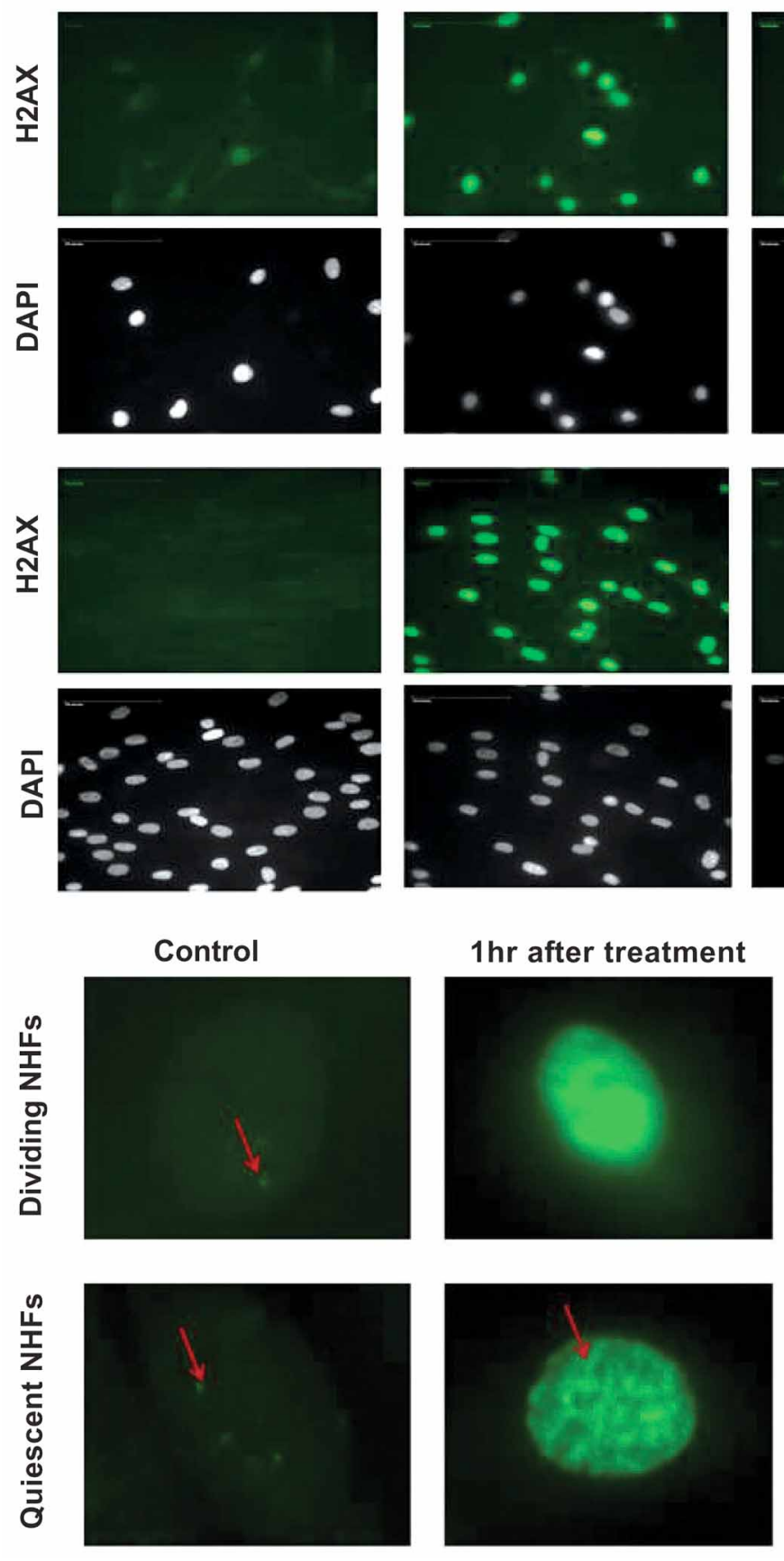

\section{$24 \mathrm{hr}$ post treatment}
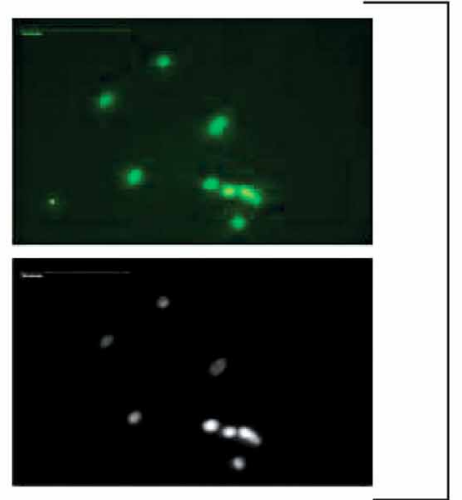

\section{Young dividing \\ NHFs}

\section{Quiescent \\ NHFs}

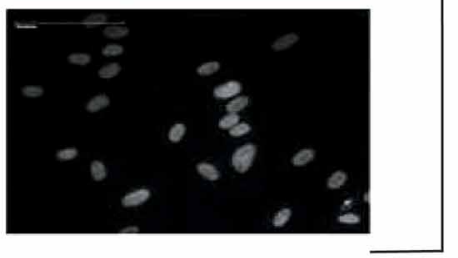

$24 \mathrm{hr}$ after treatment
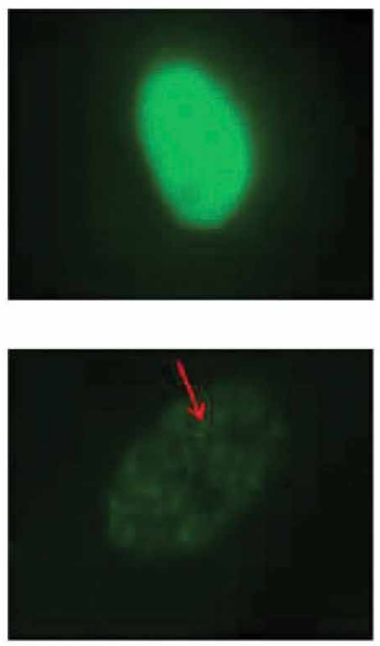

Fig. (3). External oxidative stress induced DNA double stranded breaks and DNA repair response. Young dividing NHFs and quiescent NHFs were treated with $500 \mu \mathrm{M} \mathrm{H}_{2} \mathrm{O}_{2}$, subjected to $\mathrm{H} 2 \mathrm{AX}$ and DAPI staining, as described in Materials and Methods section. Positive H2AX staining indicated phosphorylated histone H2AX corresponding to DNA double stranded breaks repair. Pictures were taken at 400x magnification (A). Detailed view $(2400 x)$ of the nuclei is provided in $(\mathbf{B})$.

in quiescent cells treated with a high dose of external oxidative stress (Fig. 4B), whereas untreated quiescent NHFs resumed normal cell growth after sub-culturing (Fig. 4A). This observation indicated that treated quiescent cells may be undergoing senescence. To confirm the senescent state of the treated quiescent NHFs, we looked for the senescence specific marker Senescence-Associated (SA) $\beta$ - galactosidase [5]. SA $\beta$-galactosidase assay was performed in untreated and $\mathrm{H}_{2} \mathrm{O}_{2}$ treated quiescent NHFs following subculturing, as described in Materials and Methods (Fig. 5). Cells sub-cultured after $\mathrm{H}_{2} \mathrm{O}_{2}$ treatment stained positively upon exposure to $\mathrm{x}$-gal, which is indicative of senescence phenotype, while the control cells were negative. These results indicate that high dose oxidative stress induces premature senescence in quiescent cells. 

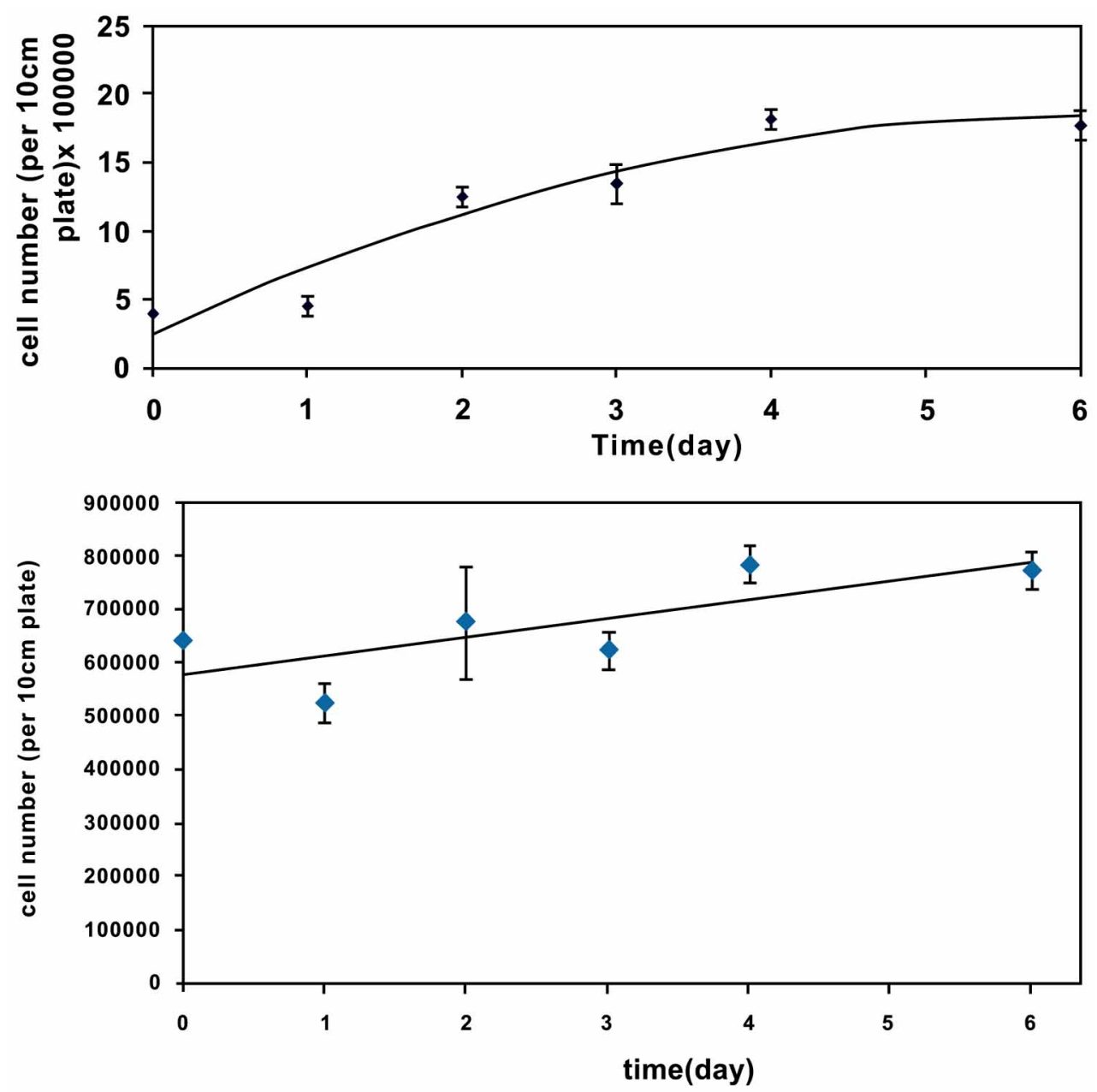

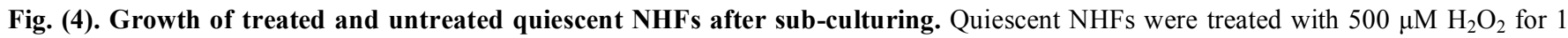
hour, after which they were allowed to recover for 24 hours and then sub-cultured. The number of cells in the culture was monitored over a period of 6 days, starting at the time when they were seeded into new plates. Control cells resumed normal cell growth (A), while the treated ones did not grow and change their number significantly $(\mathbf{B})$.

Quiescent NHF untreated

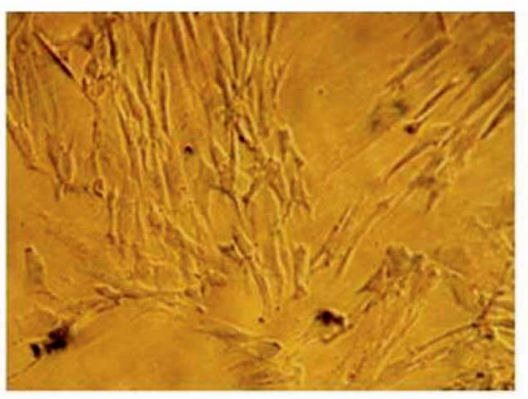

Quiescent NHF treated with $500 \mu \mathrm{M}$

$$
\mathrm{H}_{2} \mathrm{O}_{2}
$$

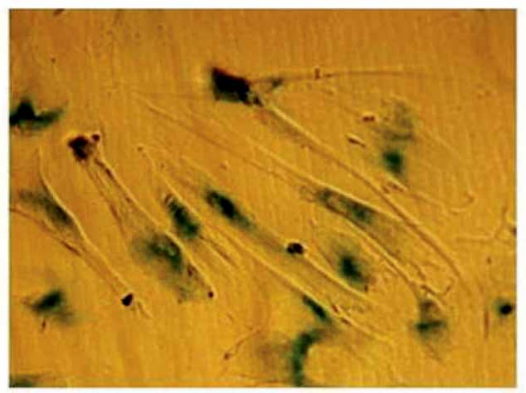

Fig. (5). Induction of Senescence-Associated $\beta$-galactosidase expression in quiescent $\mathrm{NHFs}$ following $\mathrm{H}_{2} \mathrm{O}_{2}$ treatment. Quiescent NHFs, untreated and those treated with $500 \mu \mathrm{M} \mathrm{H}_{2} \mathrm{O}_{2}$ for 1 hour. Twenty four hours following treatment, they were sub-cultured, fixed in $3 \%$ paraformaldehyde and stained with x-gal as described in Materials and Methods section. Pictures were taken at 100x magnification; positive stain is observed only in senescent fibroblasts.

\section{Levels of ROS in Young Dividing and Quiescent NHFs}

In order to explain the differential behaviour of quiescent NHFs we determined the level of reactive oxygen species
(ROS) in young dividing and quiescent NHFs both $\mathrm{H}_{2} \mathrm{O}_{2}$ treated and untreated. We measured total cellular ROS in young dividing and quiescent cells with or without $\mathrm{H}_{2} \mathrm{O}_{2}$ treatment using $\mathrm{H}_{2}$ DCFDA as described in Materials and 


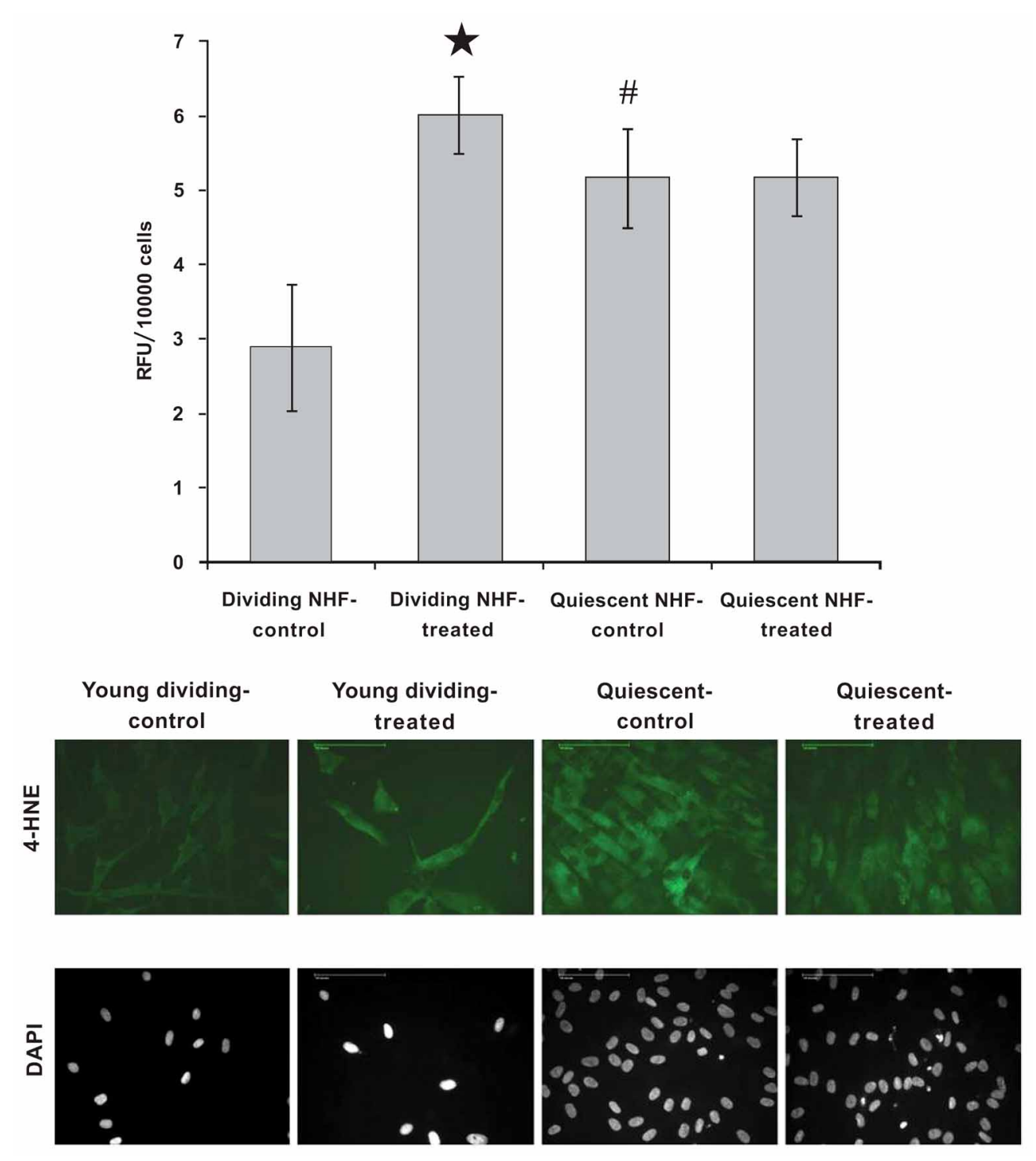

Fig. (6). (A) Production of ROS in sub-confluent and quiescent cells before and after the treatment. NHF (PD 26) cells were grown either to $50 \%$ (dividing) or to $100 \%$ (quiescent) confluence, treated with $500 \mu \mathrm{M} \mathrm{H}_{2} \mathrm{O}_{2}$ for 1 hour to induce oxidative stress and then allowed to recover for 24 hours. Then the cells were incubated with $10 \mu \mathrm{M}$ DCFDA as described in Materials and Methods section. Statistically significant differences are shown as: $\star$ between untreated (control) and treated young dividing cells, $\mathrm{p}<0.05$ and \# between untreated/control young dividing and quiescent cells. (B) Lipid peroxidation in dividing and quiescent cells before and after the treatment. Young dividing NHFs and quiescent NHFs were treated with $500 \mu \mathrm{M} \mathrm{H}_{2} \mathrm{O}_{2}$ for 1 hour, after which they were allowed to recover for 24 hours. They were then stained for 4-HNE and DAPI as described in Materials and Methods section. Pictures were taken at 400x magnification. Cellular oxidative stress was indicated by positive 4-HNE staining and it was observed in young dividing NHFs following oxidative stress and quiescent NHFs both treated and non-treated. DAPI was used to simultaneously observe DNA damage. Only young dividing NHFs following the oxidative stress show significant chromatin condensation. (C) Protein nitrosylation in dividing and quiescent cells before and after the treatment. Young dividing NHF, and quiescent NHF were treated with $500 \mu \mathrm{M} \mathrm{H}_{2} \mathrm{O}_{2}$ for 1 hour, after which they were allowed to recover for 24 hours. They were then immunostained using anti-nitrotyrosine (NT) antibody as described in Materials and Methods section. Pictures were taken at 400x magnification. Cellular oxidative stress was indicated by positive NT staining and it was observed in young dividing NHFs following oxidative stress and quiescent NHFs both treated and non-treated. DAPI was used to simultaneously observe DNA damage. Only young dividing NHFs following the oxidative stress show significant chromatin condensation.

Methods section. Untreated dividing NHFs had the lowest level of ROS, while treated young dividing NHFs had the highest (untreated versus treated dividing cells, $\mathrm{p}<0.05$ ), which might sensitize them to apoptosis (Fig. 6A). Untreated quiescent NHFs had naturally higher ROS levels compared to young dividing NHFs (untreated quiescent versus young dividing cells $\mathrm{p}<0.05)$ and ROS levels did not change significantly following exposure to external oxidative stress (Fig. 6A). This might lead to the conclusion that quiescent NHFs, by having a higher level of endogenous ROS, are better conditioned for dealing with oxidative stress and therefore do not enter the apoptotic pathway, but rather, 
become senescent. Higher endogenous ROS leads to lipid peroxidation and protein nitrosylation, and so we monitored the level of oxidative damage to lipid and proteins using anti-4-hydroxy-2-nonenal (4HNE) and anti-nitrotyrosine (NT) antibodies, as described in Materials and Methods section. There is a clear indication of lipid peroxidation and protein nitrosylation in NHFs undergoing apoptosis (Fig. 6B, C). Similarly, high level of ROS in quiescent NHFs, both treated and untreated, is correlated with increased oxidative damage to lipids and proteins (Fig. 6B, C). These results indicate that quiescent NHFs, even though resistant to apoptosis, have undergone protein and lipid oxidative modification.

\section{$\mathrm{H}_{2} \mathrm{O}_{2}$ Treatment of Quiescent NHFs does not Affect Mitochondria}

Once we determined the differential ROS levels in young dividing and quiescent NHFs, we wanted to determine if mitochondrial membrane potential (MMP) is affected in these cells. Both dividing and quiescent NHFs were stained with the MMP-sensitive fluorescent JC-1 dye $24 \mathrm{hrs}$ following $\mathrm{H}_{2} \mathrm{O}_{2}$ treatment, as described in Materials and Methods. Mitochondria that maintain MMP show red fluorescence due to accumulation and aggregation of JC-1 inside the mitochondria. Loss of MMP is evident only in treated young dividing NHFs (which were sensitive to oxidative stress and underwent apoptosis). To our surprise, quiescent NHFs maintained healthy MMP even after being exposed to such a high dose of $\mathrm{H}_{2} \mathrm{O}_{2}$ (Fig. 7). Therefore, external oxidative stress does not lead to mitochondrial collapse in quiescent NHFs, indicating that these cells might have a mechanism to protect the mitochondria against oxidative stress.

\section{Up-Regulation of MnSOD and Maintenance of Non- Selenium Glutathione Peroxidise Expression in Quiescent NHFs}

In order to better understand the resistance of quiescent NHFs to oxidative stress induced apoptosis, and possibly reveal some mechanism involved in coping with the excess ROS while maintaining healthy mitochondria, we investigated the protein levels of Manganese Superoxide Dismutase (Mn-SOD) and non-Selenium glutathione peroxidase. In young dividing cells, Mn-SOD is expressed at low levels, whereas in quiescent NHFs it is upregulated and remains high even after treatment (Fig. 8a, b). High levels of MnSOD might be responsible for efficient removal of superoxide in mitochondria, thus protecting it from oxidative damage. Non-selenium glutathione peroxidase is expressed at approximately the same level in young dividing and quiescent NHFs, and it continues to be expressed in quiescent NHFs after $\mathrm{H}_{2} \mathrm{O}_{2}$ treatment. However, this is not the case with young dividing treated NHFs (undergoing apoptosis) where non-selenium glutathione peroxidase is

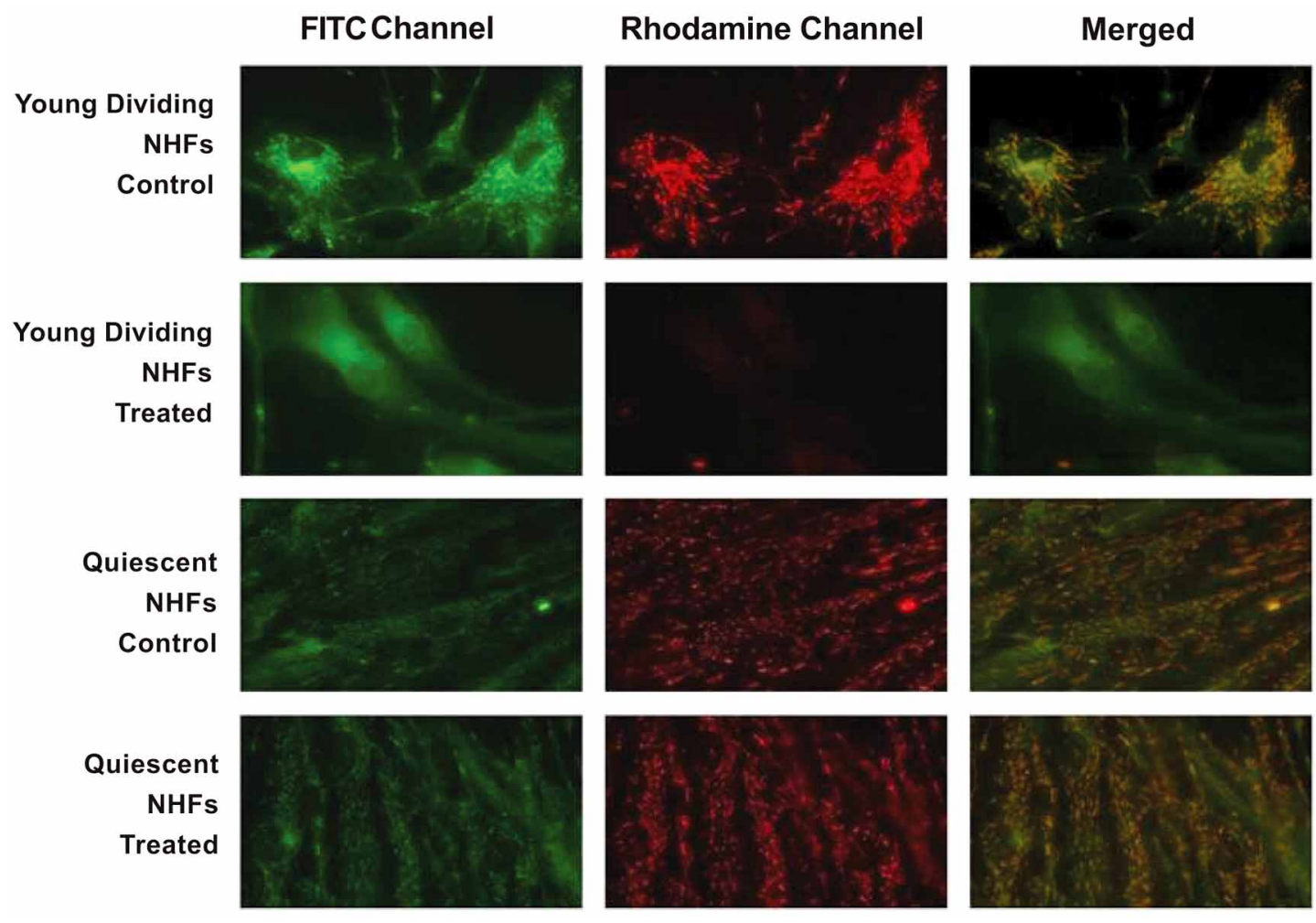

Fig. (7). Mitochondrial membrane potential (MMP) in dividing and quiescent cells before and after the treatment. NHF cells were grown either to $50 \%$ (young dividing NHFs) or to $100 \%$ confluence (quiescent NHFs), treated with $500 \mu \mathrm{M} \mathrm{H}_{2} \mathrm{O}_{2}$ for 1 hour to induce oxidative stress and allowed to recover for 24 hours, stained with JC-1 as described in Materials and Methods section. Mitochondrial potential was evaluated using JC-1 staining and fluorescent microscopy; pictures were taken at 400x magnification. Young dividing NHFs at $50 \%$ confluence had healthy mitochondria as indicated by the red stain. Mitochondria of young dividing NHFs post treatment started collapsing as indicated by the absence of red staining. Quiescent NHFs, both untreated and treated, showed intact mitochondria. 
A

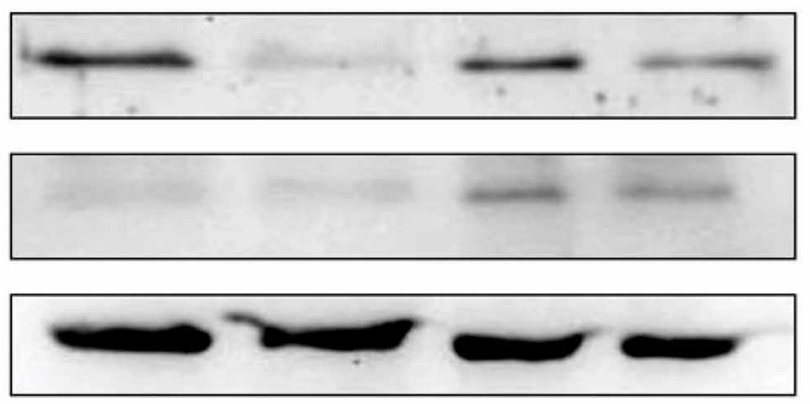

\section{Non Selenium Glutathione}

Peroxidase

\section{MnSOD}

\section{Actin}
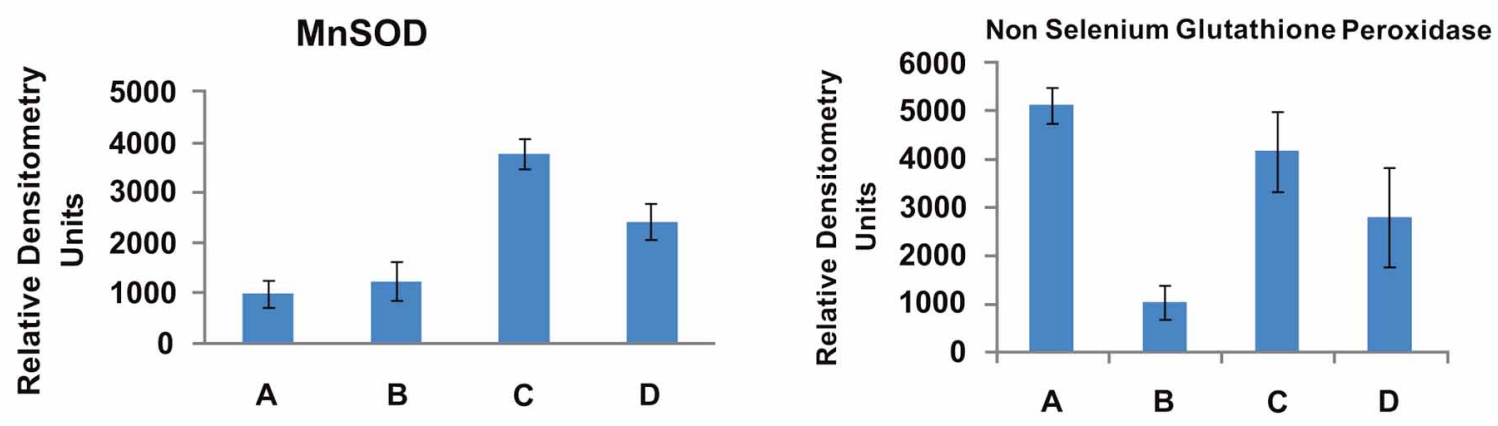

\section{Non Selenium Glutathione}

Fig. (8a). Expression of MnSOD and non-selenium glutathione peroxidise in dividing and quiescent NHFs before and after the treatment. NHF (PD 28 and PD 29) cells were grown either to 50\% (young dividing NHFs) or to 100\% confluence (quiescent NHFs), treated with $500 \mu \mathrm{M} \mathrm{H}_{2} \mathrm{O}_{2}$ to induce oxidative stress, and harvested after $24 \mathrm{hrs}$. Equal amount of protein $(20 \mu \mathrm{g})$ from post nuclear cell lysate of was used for immunoblotting as described in Materials and Methods section. A) Young dividing NHF- control; B) Young dividing NHFtreated; C) Quiescent NHF-control; D) Quiescent NHF- treated.8b. Relative densitometry units for MnSOD using Image J software. 8c. Relative densitometry units for non selenium glutathione reductase using Image $\mathrm{J}$ software.

almost entirely absent (Fig. 8a, c). Therefore, it is possible that these enzymes might play a role in protecting quiescent NHFs' mitochondria.

Induction of p21 and Down-Regulation of Bax in Quiescent NHFs Following $\mathrm{H}_{2} \mathrm{O}_{2}$ Treatment

In addition to enzymes responsible for anti-oxidative defence (as described above), we wanted to investigate the expression of other pro- and anti-apoptotic, as well as cell cycle-arrest-related proteins in young dividing and quiescent NHFs before and after the treatment. p21 is known to block cells in G1 stage of cell cycle and as expected p21 is overexpressed in quiescent cells. Interestingly, we observed that p21 was further over-expressed in quiescent cells after $\mathrm{H}_{2} \mathrm{O}_{2}$ treatment (Fig. 9a, c), indicating its possible role in inducing senescence (permanent cell cycle arrest). Dividing NHFs exposed to external oxidative stress undergo apoptosis not senescence, which may be attributed to the involvement of Bcl-2 family proteins, such as Bax and Bcl-2. Bax is a proapoptotic protein and $\mathrm{Bcl}-2$ is anti-apoptotic protein; the ratio between these proteins dictates cell death or survival. As expected, treated dividing NHFs undergoing apoptosis show up-regulation of Bax and down-regulation of Bcl-2 (Fig. 9a, b, d). Interestingly, Bax is down-regulated in quiescent NHFs treated with $\mathrm{H}_{2} \mathrm{O}_{2}$. Furthermore, Bcl-2 levels are unchanged after treatment (Fig. 9a, d). These observations further indicate that quiescent cells have a protein expression profile consistent with resistance to apoptosis and in favour of senescence.

\section{DISCUSSION}

We report for the first time that quiescent Normal Human Fibroblasts enter premature senescence upon brief exposure (1 hr) to $500 \mu \mathrm{M} \mathrm{H}_{2} \mathrm{O}_{2}$. It has been previously reported that repeated exposure of normal human fibroblasts to subcytotoxic oxidative stress induces premature cellular senescence [23, 24], but our study demonstrates that premature senescence can be induced by a single high dose of $\mathrm{H}_{2} \mathrm{O}_{2}$ when fibroblasts are in a quiescent state. This 

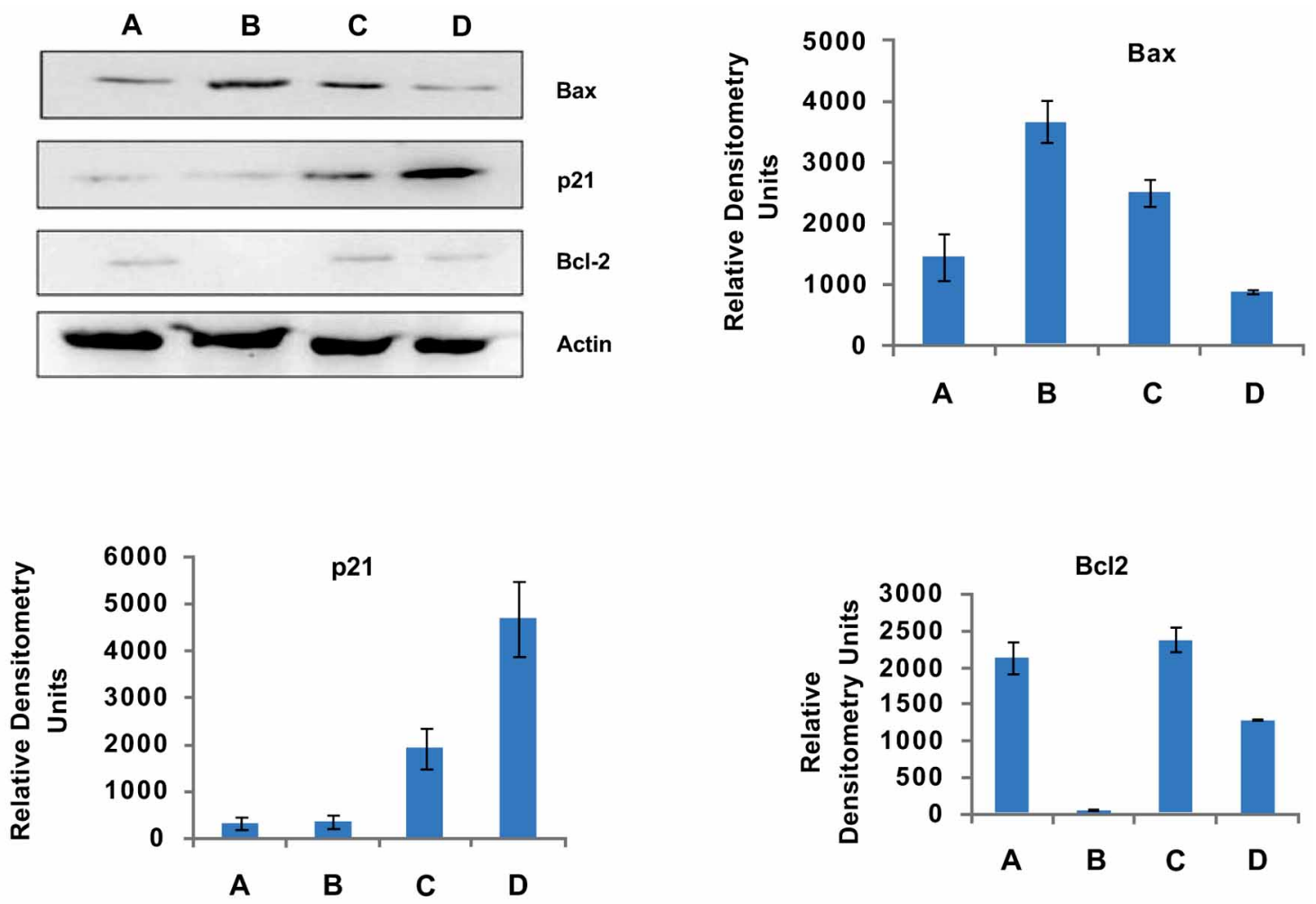

Fig. (9a). Expression of p21, Bax, and Bcl2 in dividing and quiescent NHFs before and after the treatment. NHF (PD 28 and PD 29) cells were grown either to $50 \%$ (young dividing NHFs) or to $100 \%$ confluence (quiescent $\mathrm{NHFs}$ ), treated with $500 \mu \mathrm{M} \mathrm{H}_{2} \mathrm{O}_{2}$ to induce oxidative stress, and harvested after $24 \mathrm{hrs}$. Equal amount of protein $(20 \mu \mathrm{g})$ from post nuclear cell lysate of was used for immunoblotting as described in Materials and Methods section. A) Young dividing NHF- control; B) Young dividing NHF-treated; C) Quiescent NHF-control; D) Quiescent NHF- treated.9b-d. Relative densitometry units for Bax (9b), p21 (9c) and $\mathrm{Bcl}_{2}(\mathbf{9 d})$.

method allowed for obtaining large amounts of senescent cells in a shorter period of time.

Unlike dividing NHFs which undergo apoptosis following a high dose of oxidative stress, quiescent NHFs exhibited resistance to this dose and become senescent. We have previously reported that only dividing (not quiescent) NHFs exhibited p38MAPK activation following $\mathrm{H}_{2} \mathrm{O}_{2}$ treatment and became apoptotic while quiescent cells were unaffected [19]. Induction of apoptosis by $\mathrm{H}_{2} \mathrm{O}_{2}$ treatment in dividing cells was evident by chromatin condensation and DNA fragmentation. Quiescent cells on the other hand did not show chromatin condensation or DNA fragmentation following treatment; however, they did show successful, albeit incomplete, repair of double stranded DNA breaks. Furthermore, there is a clear difference in the expression of pro- and anti-apoptotic proteins in dividing and quiescent fibroblasts following $\mathrm{H}_{2} \mathrm{O}_{2}$ treatment. While dividing NHFs showed up-regulation of Bax protein and down-regulation of anti-apoptotic Bcl-2, quiescent cells exhibited downregulation of Bax and no change in Bcl-2 level. Interestingly, p21, a cell cycle arrest protein, which was already present in higher amounts in contact-inhibited quiescent cells, was further up-regulated after $\mathrm{H}_{2} \mathrm{O}_{2}$ treatment. This result implicates the importance of p21 in the onset of senescence. Indeed, $\mathrm{H}_{2} \mathrm{O}_{2}$ treated quiescent NHFs had a senescent phenotype and tested positive for SA- $\beta$-galactosidase, a characteristic marker of senescence [5]. The question now becomes: why are quiescent fibroblasts resistant to oxidative stress-induced apoptosis and why do they enter senescence after $\mathrm{H}_{2} \mathrm{O}_{2}$ treatment?

Oxidative stress-induced DNA damage, depending on the extent, can lead to either cell death or senescence through a common p53 mechanism [14]. If the DNA damage is not severe enough to induce apoptosis, then cellular senescence occurs [16]. Our observations indicate that a high dose of external oxidative stress actually caused a substantial amount of DNA double stranded breaks in quiescent cells, but an active DNA repair response was initiated. Since the DNA was not entirely repaired, the quiescent cells did not continue through normal cell cycling. Even though the DNA damage was insufficient to cause apoptosis in these cells it was enough to cause senescence.

In addition to DNA damage, $\mathrm{p} 21$ protein is implicated in the onset of senescence. The cell cycle inhibitor p21 is responsible for exerting G1 cell cycle arrest after DNA damage [25]. It has been also reported that $\mathrm{p} 21$ protects HST116 colon carcinoma cells against hyperoxia [26], which supports our finding that $\mathrm{H}_{2} \mathrm{O}_{2}$ treated quiescent NHF cells are resistant to oxidative stress-induced apoptosis. Furthermore, down-regulation of p21 transcription promotes a p53-dependant apoptotic response to genomic stress [27]. Therefore, p21 promotes cell survival by limiting p53dependent apoptosis. It has also been reported by Sohn et al. (2006) [28] that p21 is able to protect cells from IR-induced apoptosis by suppressing CDK activity, which seems to be 
needed to activate the caspase-cascade downstream of the mitochondria. Our observation that p21 is up-regulated in quiescent fibroblasts and is further up-regulated post $\mathrm{H}_{2} \mathrm{O}_{2}$ treatment supports the pro-survival role of $\mathrm{p} 21$. Upregulation of p21 in quiescent NHFs before and after exposure to oxidative stress may therefore protect cells from oxidative stress-induced apoptosis directly, not merely block their division by locking them in G1.

Bcl-2 expression was maintained in quiescent cells following $\mathrm{H}_{2} \mathrm{O}_{2}$ treatment, and thus they were protected from apoptosis. Bcl-2 has been found to decrease hyperoxiainduced apoptotic cell death by preventing caspase activation and the release of pro-apoptotic factors cytochrome $c$ and AIF from the mitochondria [29]. Increased levels of ROS do not cause significant damage in quiescent $\mathrm{H}_{2} \mathrm{O}_{2}$ treated fibroblasts; these cells may activate cellular anti-oxidant defence mechanisms against major oxidative insult, which might be the reason why quiescent NHFs resist apoptosis. Bcl-2 over-expression might lead to protection against oxidative stress and cell cycle arrest that could promote senescence [29]. Quiescent NHFs retained Bcl-2 expression levels even after $\mathrm{H}_{2} \mathrm{O}_{2}$ treatment, while young dividing NHFs exhibited null Bcl-2 expression; quiescent NHFs became senescent after $\mathrm{H}_{2} \mathrm{O}_{2}$ treatment, highlighting the importance of Bcl-2 in both pro-survival and senescencepromoting cellular responses. Dividing fibroblasts treated with $\mathrm{H}_{2} \mathrm{O}_{2}$ showed the expected marked increase in Bax levels, which coincides with other apoptotic events observed in these cells following treatment.

Endogenous $\mathrm{H}_{2} \mathrm{O}_{2}$ in quiescent cells did not change significantly after treatment with a high dose of oxidative stress, which suggests an enhanced anti-oxidative cellular mechanism. We have observed that MnSOD is up-regulated in quiescent fibroblasts and continues to demonstrate upregulation even after $\mathrm{H}_{2} \mathrm{O}_{2}$ treatment (Fig. 8). We then suspected involvement of MnSOD in resistance of quiescent fibroblasts to high levels of external oxidative stress. MnSOD is a mitochondrial enzyme and is considered to be front-line of defence against external oxidative stress. It has been reported recently that superoxide dismutase-3 (SOD-3), as well as peroxiredoxin 4 (PRDX4) and epoxide hydrolase (EPHX1) are the up-regulated genes responsible for protecting the cell against the accumulating damage, such as that caused by oxidative stress, and for preserving reversibility of quiescence [30]. It has been also previously reported that MnSOD up-regulation induced by Resveratrol leads to oxidative stress resistance in the human lung fibroblast cell line MRC-5 [31]. MnSOD was found to have a crucial role in regulating transition between proliferative growth and quiescence. Increased MnSOD activity was linked to quiescence in mouse embryonic fibroblasts, while decreased levels lead to proliferative growth [32]. We postulate that up-regulated MnSOD in quiescent fibroblasts might be responsible for superoxide being sequestered from the mitochondria, thus keeping the mitochondria active even after exposure to a high dose of $\mathrm{H}_{2} \mathrm{O}_{2}$ (Fig. 7). Indeed, our results indicate that mitochondrial membrane potential is maintained following $\mathrm{H}_{2} \mathrm{O}_{2}$ treatment in quiescent cells. Excess $\mathrm{H}_{2} \mathrm{O}_{2}$ caused some oxidative damage to cellular macromolecules, which was indicated by lipid peroxidation and protein nitrosylation; however, it is important to emphasize that no additional oxidative damage was observed in the treated quiescent fibroblasts compared to untreated controls. Maintaining healthy mitochondria by up-regulation of MnSOD seems to be a crucial event in resistance to apoptosis.

Quiescent fibroblasts, which have up-regulated MnSOD and $\mathrm{p} 21$, are able to withstand a high dose of external oxidative stress by entering into permanent cell cycle arrest or senescence. MnSOD and p21 up-regulation, maintenance of Bcl-2 levels and Bax down-regulation are largely responsible for quiescent cell survival after $\mathrm{H}_{2} \mathrm{O}_{2}$ treatment. More importantly, even though DNA damage was substantial in treated quiescent cells, they were able to repair their DNA; however, this repair was not complete and thus the cells entered senescence. As proposed, cells with DNA damage that do not become apoptotic may become senescent as a safeguard against tumorigenesis [3]. Apoptosis, SIPS and replicative senescence seem to share a common pathway, although it remains largely unclear as to how a cell's fate is ultimately determined.

\section{ACKNOWLEDGEMENTS}

This work was supported by Natural Science and Engineering Research Council (NSERC) of Canada. The authors would like to thank Carly Griffin for critically reviewing the manuscript and Ms Sudipa June Chatterjee for her help in the revision of the MS.

\section{ABBREVIATIONS}

$$
\begin{aligned}
& \text { 4-HNE }=\text { 4-hydroxy-2-nonenal } \\
& \text { MMP }=\text { Mitochondrial membrane potential } \\
& \text { ROS }=\text { Reactive oxygen species } \\
& \text { SIPS }=\text { Stress induced premature senescence } \\
& \text { TUNEL }=\text { Terminal dUTP Nick End Labeling }
\end{aligned}
$$

\section{REFERENCES}

[1] Harman D. Extending functional life span. Exp Gerontol 1998; 33(1-2): 95-112.

[2] Hayflick L, Moorhead PS. The serial cultivation of human diploid cell strains. Exp Cell Res 1961; 25: 585-621.

[3] Campisi J, Kim SH, Lim CS, Rubio M. Cellular senescence, cancer, and aging: The telomere connection. Exp Gerontol 2001; 36: 1619-37.

[4] Bodnar AG, Oullette M, Frolkis M, et al. Extension of life-span by introduction of telomerase into normal human cells. Science 1998; 279: 349-52.

[5] Dimri GP, Lee X, Basile G, et al. A biomarker that identifies ageing human cells in culture and in ageing cells in vivo. Proc Natl Acad Sci USA 1995; 92: 9363-7.

[6] Hayflick L. The cellular basis for biological aging. In: Finch C; Hayflick L, Eds. Handbook of the biology of ageing. New York, Van Nostrand Reinhold 1977: 159-86.

[7] Toussaint O, Medranos EE, von Zglinicki T. Cellular and molecular mechanisms of stress induced premature senescence (SIPS) of human diploid fibroblasts and melanocytes. Exp Gerontol 2000; 35: 927-45.

[8] Chen Q, Fischer A, Raegan JD, Yan LJ, Ames BN. Oxidative DNA damage and senescence of human diploid fibroblast cells. Proc Natl Acad Sci USA 1995; 92: 4337-41.

[9] Campisi J. Senescent cells, tumour suppression, and organismal aging: Good citizens, bad neighbours. Cell 2005; 120: 513-22.

[10] Honda S, Hjelmeland LM, Handa JT. Oxidative stress induced single strand breaks in chromosomal telomeres of human retinal 
pigment epithelial cells in vitro. Invest Opthalmol Vis Sci 2001; 42: $2139-44$

[11] Toussaint O, Houbion A, Remacle J. Aging as a multi-step process characterized by lowering of entropy production leading the cell to a sequence of defined stages. II. Testing some predictions on aging human fibroblasts in culture. Mech Ageing Dev 1992; 65: 65-83.

[12] Rodemann HP, Bayreuthe K, Francz PI, Dittmann K, Abbiez M. Selective enrichment and biochemical characterization of seven human skin fibroblast cells in vitro. Exp Cell Res 1989; 180: 84-93.

[13] Dumont P, Chen QM, Burton M, et al. Induction of replicative senescence biomarkers by sublethal oxidative stresses in normal human fibroblast. Free Radic Biol Med 2000; 28: 361-73.

[14] Itahana K, Dimri G, Campisi J. Regulation of cellular senescence by p53. Eur J Biochem 2001; 268: 2784-91.

[15] De Boer J, Hoeijmakers JHJ. Nucleotide excision repair and human syndromes. Carcinogenesis 2000; 21: 453-60.

[16] Beckman KB, Ames BN. The free radical theory of ageing matures. Physiol Rev 1998; 78: 547-81.

[17] Vaziri H, West MD, Allsopp RC, et al. ATM-dependent telomere loss in aging human diploid fibroblasts and DNA damage lead to the post-translational activation p53 protein involving poly(ADPribose) polymerase. EMBO J 1997; 16: 6018-33.

[18] von Zglinicki T, Pilger R, Sitte N. Accumulation of single strand breaks is the major cause of telomere shortening in human fibroblasts. Free Radical Biol Med 2000; 28: 64-74.

[19] Naderi J, Hung M, Pandey S. Oxidative stress induced apoptosis in dividing fibroblasts involves activation of p38MAP Kinase and overexpression of Bax: Resistance of quiescent cells to oxidative stress. Apoptosis 2003; 8: 91-100.

[20] Siraki AG, Pourahmad J, Chan TS, Khon S, O'Brien PJ. Endogenous and endobiotic reactive oxygen species formation by isolated hepetocytes. Free Radic Biol Med 2002; 32: 2-10.

[21] Yang J, Hooper WC, Phillips DJ, Talkington DF. Regulation of proinflammatory cytokines in human lung epithelial cells infected with Mycoplasma pneumoniae. Infect Immunol 2002; 70: 3649-55.

[22] Zhao H, Tanaka T, Halicka HD, et al. Cytometric assessment of DNA damage by exogenous and endogenous oxidants reports aging-related processes. Cytometry A 2007; 71(11): 905-14.
[23] Frippiat C, Chen QM, Zdanov S, Magalhaes JP, Remacle J, Toussaint $\mathrm{O}$. Subcytotoxic $\mathrm{H}_{2} \mathrm{O}_{2}$ stress triggers a release of transforming growth factor-beta 1 , which induces biomarkers of cellular senescence of human diploid fibroblasts. J Biol Chem 2001; 76(4): 2531-7.

[24] Caldini R, Chevanne M, Mocali A, Tombaccini D, Paoletti F. Premature induction of aging in sublethally $\mathrm{H}_{2} \mathrm{O}_{2}$-treated young MRC5 fibroblasts correlates with increased glutathione peroxidase levels and resistance to DNA breakage. Mech Ageing Dev 1998; 105(1-2): 137-50.

[25] Waldman T, Kinzler KW, Vogelstein B. p21 is necessary for the p53-mediated G1 arrest in human cancer cells. Cancer Res 1995; 55: 5187-90.

[26] Helt CE, Rancourt RC, Staversky RJ, O'Reilly MA. p53-dependent induction of $\mathrm{p} 21 \mathrm{Cip} 1 / \mathrm{Waf} 1 / \mathrm{Sdi} 1$ protects against oxygen-induced toxicity. Toxicol Sci 2001; 63: 214-22.

[27] Seoane J, Le HV, Massague J. Myc suppression of the p21 (Cip1) Cdk inhibitor influences the outcome of the p53 response to DNA damage. Nature 2002; 419: 729-34.

[28] Sohn D, Essmann F, Schulze-Osthoff K, Jänicke RU. p21 blocks irradiation-induced apoptosis downstream of mitochondria by inhibition of cyclin-dependent kinase-mediated caspase-9 activation. Cancer Res 2006; 66(23): 11254-62.

[29] López-Diazguerrero NE, López-Araiza H, Conde-Perezprina JC, et al. Bcl-2 protects against oxidative stress while inducing premature senescence. Free Radic Biol Med 2006; 40(7): 1161-9.

[30] Coller HA, Sang L, Roberts JM. A new description of cellular quiescence. PLoS Biol 2006; 4(3): e83.

[31] Robb EL, Page MM, Wiens BE, Stuart JA. Molecular mechanisms of oxidative stress resistance induced by resveratrol: Specific and progressive induction of MnSOD. Biochem Biophys Res Commun 2008; 367(2): 406-12.

[32] Sarsour EH, Venkataraman S, Kalen AL, Oberley LW, Goswami PC. Manganese superoxide dismutase activity regulates transitions between quiescent and proliferative growth. Aging Cell 2008; 7(3): 405-17.

(C) Domazet-Damjanov et al.; Licensee Bentham Open.

This is an open access article licensed under the terms of the Creative Commons Attribution Non-Commercial License (http://creativecommons.org/licenses/by$\mathrm{nc} / 3.0 /$ ), which permits unrestricted, non-commercial use, distribution and reproduction in any medium, provided the work is properly cited. 